(C) 2013

Скриль В. Ю., асистент

Полтавська державна аграрна академія

\title{
ЕФЕКТИВНІСТЬ ВИКОРИСТАННЯ УЛЬТРАФІОЛЕТОВОГО ІНТРАВАСКУЛЯРНОГО ЛАЗЕРНОГО ОПРОМІНЕННЯ КРОВІ ЗА ЛІКУВАННЯ КОНЕЙ ІЗ ТРАВМАМИ ОПОРНО-РУХОВОГО АПАРАТУ
}

\author{
Рецензент - кандидат ветеринарних наук К. В. Супруненко
}

Представлені результати ефективності вико ристання ультрафіолетового інтраваскулярного лазерного опромінення крові за лікування коней із травмами опорно-рухового апарата за динамікою клінічних показників. Доведено, щуо n'ятиразове опромінення крові один раз на добу тривалістю десять хвилин у поєднанні з локальним втиранням крему для суглобів «Алезан» порівняно лише 3 його місцевим застосуванням є більш ефективним методом, оскільки реєструється тенденція до швидшого зникання культавості та ознак запальної реакиії.

Ключові слова: лазерне опромінення крові, травми у коней.

Постановка проблеми. Сучасна система тренінгу спортивних коней та участь їх у змаганнях пов'язана 3 серйозними навантаженнями на опорно-руховий апарат і поєднана 3 максимальною мобілізацією всіх систем організму, що обумовлює збільшення ймовірності й тяжкості травматизму, зниження спортивного довголіття i погіршення результатів виступів у змаганнях. У вирішенні проблеми даної хірургічної патології у спортивних коней важливим $\epsilon$ вибір безпечних та екологічно чистих методів і засобів терапії, що забезпечують високий позитивний ефект за короткі терміни.

Розробка безмедикаментозної терапії становить значний інтерес для ветеринарної практики [2]. У зв'язку з погіршенням екології, умов життя й годівлі тварин, застосування лікарських засобів нерідко виявляється малоефективним i, всупереч очікуваному ефекту, часто-густо призводить до розвитку ускладнень, таких як алергічні реакції, дисбактеріоз кишечника, порушення функцій печінки та нирок. Квантова ж терапія (КТ), що в останні роки широко впроваджується у ветеринарну практику, відноситься до одного 3 ефективних методів безмедикаментозної терапії тварин. Різноманітні методи квантової терапії використовуються як у якості самостійного методу профілактики й лікування, так і у комплексі 3 лікарськими засобами $[1,3]$. Лікувальний ефект виникає внаслідок впливу низькоенергетичних електромагнітних випромінювань кван- тів. У основі біологічного квантового випромінювання лежить його здатність проявляти антиоксидантну дію, що приводить до нормалізації мембранних і метаболічних процесів, а також підсилює здатність до компенсаторного посилення мікроциркуляції. В такому разі лікувальні фактори діють одночасно, взаємно посилюючи один одного, що забезпечує більшу глибину проникнення енергії в тканини та більш прискорений розвиток відповідної реакції організму [4].

Аналіз основних досліджень і публікацій, у яких започатковано розв'язання проблеми Існуючі методи лікування травм у спортивних коней не завжди дають високий терапевтичний ефект, і тому вельми актуальним $є$ питання вдосконалення відомих традиційних лікувальних засобів і методів. Доцільним на сучасному етапі розвитку ветеринарної науки є доопрацювання методів лікування тварин із метою стимуляції загальної резистентності організму.

Завдяки розробкам вітчизняних і зарубіжних учених та передових виробництв практична ветеринарія збагатилася найрізноманітнішими методами боротьби з незаразними хворобами. Так, фізіотерапія, підвищуючи резистентність організму, прискорює одужання тварин і зменшує або виключає в таких випадках використання цілої низки хіміотерапевтичних препаратів.

Зокрема, про позитивний ефект від локального застосування квантової енергї̈ за лікування гострих асептичних міозитів у спортивних коней у поєднанні з лініментом «Арніка», димексидом, а також зігріваючим гелем «Зоо VIP» повідомляє в своїй роботі Е. В. Сапожков [6]. У поодиноких дослідженнях існують також дані, в яких стверджується про результативний лікувальний ефект від інтраваскулярного лазерного опромінення крові у коней [7].

Мета дослідження: обгрунтувати можливість застосування ультрафіолетового інтраваскулярного лазерного опромінення у поєднанні з локальним застосуванням крему «Алезан» для суглобів для лікування коней із травмами опорно-рухового апарату. 


\section{BETЕРИНАРНА МЕДИЦИНА}

Завдання дослідження:

1. Сформувати контрольну та дослідну групу.

2. Опрацювати техніку ІЛОК у коней із травмами опорно-рухового атарату.

3. Встановити ефективність проведених маніпуляцій за динамікою клінічних показників.

Матеріали та методи. Дослідження проведені нами у період із березня по квітень 2013 р. на базі Чутівського кінно-спортивного комплексу «Тракен», де жеребцям породи Тракен із травматичними ушкодженнями опорно-рухового апарату було проведено інтраваскулярне (яремна вена) ультрафіолетове лазерне опромінення крові (ІЛОК) у поєднанні 3 локальним втиранням крему «Алезан» для суглобів (дослідна группа n=3). У контрольній групі $(\mathrm{n}=3)$ застосовували лише локальне втирання зазначеного препарату.

Для опромінення крові застосовували апарат «Матрикс-ВЛОК» із лазерною головкою КЛВЛОК, випромінюючою УФ із довжиною хвилі 0,365 мкм, потужністю 2,0 мВт (1 мВт на виході 3 світловоду). Маніпуляції проводили один раз на добу протягом п'яти діб, тривалість одного сеансу становила 10 хвилин. Локальні втирання крему (ООО «Научно-производственный центр «Агроветзащита», Росийская Федерация) проводили в ураженій ділянці тричі на добу до клінічного одужання.

Враховуючи те, що травматичні ушкодження локалізувалися на кінцівках, клінічні дослідження 3 метою діагностики та подальшого 3'ясування ефективності лікування виконували за наступною схемою (Поллітт К. К., 1995) [5]. Спочатку проводили огляд, що дало можливість встановити ступінь кульгавості та іiі тип; далі пальпували травмовану ділянку, а також 3'ясовували амплітуду пульсу на медіальній та латеральних артеріях пальця (за потреби для підтвердження отриманих даних проводили тварину кроком або риссю). Крім зазначеного також враховували динаміку симптомів запальної реакції.

Результати дослідження. Було відібрано дві групи тварин, дослід $(n=3)$ та контроль $(n=3)$. У дослідних тварин причини формування травм опорно-рухового апарата в коней були наступними. Зокрема, у жеребця Вожак 14-річного віку тракенської породи діагностували в ділянці правого стегна забій.

Оглядом у статичному положенні не виявлено відхилень опори. У ході під час руху встановлено кульгавість слабкого ступеню, що супроводжувалася вкороченням часу спирання на праву кінцівку та переносом ваги тіла на здорову кінцівку. Проводячи пальпацію в ділянці правого стегна, за помірного натискування пальцями на ділянку тварина втрачала рівновагу.

Амплітуда пульсу пальцевих артерій на хворій кінцівці за порівняння зі здоровою залишалася незмінною. Вираженим був запальний набряк, а також за натискування на тканини болючість.

У другого жеребця (Пьеро, 11-річного віку) породи тракен був встановлений діагноз «забій у ділянці внутрішньої поверхні стегна лівої тазової кінцівки».

У статичному положенні тварина тримала хвору кінцівку в підвішеному стані, спираючись лише на зачеп. Під час руху кульгавість ще більше підсилювалася.

Пальпацією внутрішньої поверхні стегна лівої тазової кінцівки виявлено болючість і формування запального набряку. Пульсація пальцевих артерій була невираженою.

У третього жеребця (Опекун, 6-річного віку) породи тракен діагностували забій у ділянці поверхневого пальцевого згинача лівої тазової кінцівки. Оглядом виявлено формування запального набряку подовженої форми у ділянці поверхневого пальцевого згинача лівої тазової кінцівки, у разі пальпації - болючість та збільшення амплітуди пульсу пальцевих артерій на ураженій кінцівці. В статичному положенні тварина вільно зберігала рівновагу у випадку проводки кроком та риссю; виявлена також кульгавість слабкого ступеню.

До складу контрольної групи також входили три тварини.

У жеребця породи тракен (Олімп, 15-річного віку) був встановлений діагноз «забій тарсального суглобу правої тазової кінцівки». Тварина вільно спиралася на уражену кінцівку, в процесі руху реєструється кульгавість слабкого ступеню. Локально - набряк, болючість, виповнення синовіальних виворотів.

У жеребця породи тракен (Пеон, 22-річного віку) встановили діагноз «забій тарсального суглобу лівої тазової кінцівки». Оглядом встановлено відведення ураженої кінцівки вбік; в процеci проводки кульгавість слабкого ступеню. В ділянці травми - болючість і запальний набряк.

У кобили породи тракен (Організація, 8-річного віку) встановлений діагноз «забій у ділянці лівої гомілки».

Спостерігаючи за твариною, встановили зменшення рухової активності на вигулі, в русі виявлена кульгавість, зокрема в разі опори на хвору кінцівку тварина різко поштовхоподібно піднімала голову догори. 
ВЕТЕРИНАРНА МЕДИЦИНА

Зміни клінічних показників за період лікування травмованих коней

\begin{tabular}{|c|c|c|c|}
\hline Кличка тварин & Діагноз & Кульгавість & Запальна реакція \\
\hline \multicolumn{4}{|c|}{ Дослідна група (n=3) } \\
\hline Вожак & $\begin{array}{c}\text { забій у ділянці правого } \\
\text { стегна }\end{array}$ & до 15-ї доби & до 12-ї доби \\
\hline Пьеро & $\begin{array}{c}\text { забій у ділянці внутрішньої } \\
\text { поверхні стегна лівої тазової } \\
\text { кінцівки } \\
\end{array}$ & до 14-ї доби & до 10-ї доби \\
\hline Опекун & $\begin{array}{c}\text { забій у ділянці } \\
\text { поверхневого пальцевого } \\
\text { згинача лівої тазової кінцівки }\end{array}$ & до 18-ї доби & до 16-ї доби \\
\hline \multicolumn{4}{|c|}{ Контрольна група $(\mathrm{n}=3)$} \\
\hline Олімп & $\begin{array}{c}\text { забій тарсального суглоба } \\
\text { правої тазової кінцівки }\end{array}$ & до 16-ї доби & до 14-ї доби \\
\hline Пеон & $\begin{array}{c}\text { забій тарсального суглоба } \\
\text { лівої тазової кінцівки }\end{array}$ & до 20-ї доби & до 18-ї доби \\
\hline Організація & $\begin{array}{l}\text { забій у ділянці } \\
\text { лівої гомілки }\end{array}$ & до 17-ї доби & до 16-ї доби \\
\hline
\end{tabular}

За пальпації ураженої ділянки виражений запальний набряк і болючість.

Як бачимо $з$ даних таблиці, у дослідній групі кульгавість зберігалася до $15,6 \pm 1,7$ доби; в той же час у контрольній повне відновлення рухової активності кінцівки реєстрували на дві доби пізніше $(17,6 \pm 1,7)$.

Відповідно, ознаки запальної реакції в дослідній групі $(12,6 \pm 2,5)$ зникали також на $3-4$ доби швидше, ніж у контрольній $(16 \pm 1,7)$.

\section{БІБЛІОГРАФІЯ}

1. Балковой И. И., Иноземиев В. П., Сергиен-

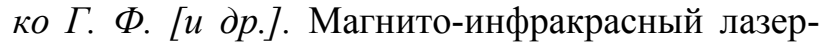
ный аппарат РИКТА-01 (М2В) в ветеринарии / Метод. пос. по прим. - М., 2000. - 146 с.

2. Иноземщев В. П., Балковой И. И., Таллер Б. Г. [u $\partial p$.$] . Лазерная терапия животных - это эффек-$ тивно и экологически безопасно // Молочное и мясное скотоводство, 1997, №4. - С. 30-32.

3. Москвин С. В. Возможные пути повышения эффективности лазерной терапии с позиций современных представлений о физиологических механизмах действия низкоинтенсивного лазерного излучения // Материалы IV Межд. конгр. «Доказательная медицина - основа современно-
Висновок. Із проведених нами досліджень можемо зробити висновок, що додаткове застосування апарата Матрикс-ВЛОК із лазерною головкою КЛ-ВЛОК, випромінюючою УФ із довжиною хвилі 0,365 мкм $є$ єфективним у випадках лікування захворювань опорно-рухового апарата в коней порівняно лише 3 локальним застосуванням крема, поскільки реєструється тенденція до швидшого зникання кульгавості $(11,3 \%)$ та ознак запальної реакції $(21,2 \%)$.

го здравоохранения». - Хабаровск : Изд. центр ИПКСЗ, 2005. - С. 181-182.

4. Москвин C. В., Буйлин В. А. Основы лазерной терапии. - Тверь : Триада, 2006. -256 с.

5. Поллитт K. К. Конечности лошадей. Иллюстрированный атлас. - Клинсленд, Австралия : Мосби, 1995. - 207 с.

6. Сапожков Е. В. Использование квантовой энергии при лечении острых асептических миозитов у спортивных лошадей. - Дисс. ... канд. вет. наук. - Воронеж, 2010. - 186 с.

7. Степаненко X.A. http://www.imperialgigant.ru/veterinar.html 